\title{
The Gender Construction of the Scythian People Under the Influence of the Transcontinental Trading Networks Approached from Interdisciplinary Methodology
}

\author{
Ruijie Yao ${ }^{1}$ \\ ${ }^{I}$ College of social and behavioral science -The University of Arizona, Tucson, Arizona, 85719 United States. \\ ruijieyao@email.arizona.edu
}

\begin{abstract}
The silk road is a grandiose conceptual idea, and the silk road has consisted of numerous civilizations with different production modes. The interactive commercial relationship between nomadic pastoralists and the agrarian society had strengthened and conjoined the Eurasian transcontinental trading networks' conceptual construction. Besides, the Scythians, the first nomadic group mentioned by the western authorship, had attracted many western scholars devoting their effort to the research of the Scythian group during the zealous time of Western-centric orientalism, and Caucasian androcentrism was still predominating the public mainstream in the western intelligentsia. The Scythian community apparatus and the idea of "Amazon" were mainly discussed under the Orientalized imaginaries about the alienated foreign outland, the existence of "Amazons," and matriarchy structure. But the application of the modern anthropological approach had provided a new point of view for reexamining the gender construction in the Scythians community, which was conducted with the archaeological methodology of interpreting material remains. Aligning with the fruition of modern archaeology and the historiography of impressive value, contemporary scholars could consolidate the fragmented historical evidence into the integral parallel. This systematic approach could help us collate the social factors played in the social construction of Scythian Femininity. The unique production mode and social engagement could become a more "scientific" criterion for approaching the females in the Scythian community, which could be interrogated from a progressive and constructionist perspective.
\end{abstract}

Keywords: Scythians community, Amazon, Gender construction, Matriarchy, Nomadic pastoralists

\section{INTRODUCTION}

The Scythian culture was one of the shiniest parts of human history, and the name of Scythians had strongly associated with the gold and the horseback archers. The ancient historians and the modern archaeologists have made a series of scholarship in the Scythian population, and the antecedent research, which included the massive fieldworks and excavation, which have revealed the emblematic pastoralist livelihood of the Scythian people. The historiography of Scythians is hard to be defined because the vast range of the time and the space that had almost passed through 1500 years in the spatial Eurasian steppe corridors had veiled the socioeconomic transformation of the Scythian cultural groups. The gender construction of the Scythian community seems lost in the vastness of societal transformation in the Eurasia transcontinental steppe. The preceding western scholarship devoted their effort into the research of Scythian group during the zealous time of Westerncentric orientalism and Caucasian androcentrism were still predominating the public mainstream in the western intelligentsia, hence, their research could possibly exist with archetypal sexism bias of classical ideology in the Eurasia study. [1-2] The Scythian community apparatus and the idea of "Amazon" was mainly discussed under the Orientalized imaginaries about the alienated foreign outland, the existence of "Amazons," and matriarchy structure.

This paper will apply both material sources and literary sources to recreate the gender identity and gender construction of the Scythian community. The first-hand 
records and archeological reports could become the effective media to recreate the ancient livelihood in the Scythian population. Applying appropriate anthropological methodology into the prehistoric gender study is a new concept. Still, the correct methodology could consolidate the fragmented historical evidence and archaeological evidence into a systematic matrix, which could help us collate social and cultural engagement in the social construction of Scythian femininity under the grandiose contexts of nomadic assemblages. The main discussion about the gender anomaly in the Scythian community was mentioned in the context of military engagement under the pastoralist environment. Although there already had some research in Herodotus' literary evidence for indicating its potential flaws. In this research paper, I will use the primary evidence from Herodotus' Historia and the archaeological site in Ak-Alakha to construct the comparative approach. Then, this comparative approach could become a complementary way to integrate the literary evidence with archaeological evidence to reconstruct the historical fact about the gender construction under the unique cultural nature of Scythian community.

\section{HISTORICAL NORM IN THE SCYTHIAN COMMUNITY}

Herodotus' Historia had first mentioned the existence of Pontic Scythians and their unique cultural landscape. Since I have noticed that nomadic groups had distinguish gendered apparatus, I started to explore the historical norm that created gender-egalitarian apparatus in the Scythian community. Although Herodotus was never stepped forward from his androcentric polymath scholar identity to evade sexism and ethnocentrism in his scholarship, his detailed depiction of Scythian people's livelihood had left a unique spectrum for helping contemporary scholars to fulfill the historical vacancy of lacking archaeological evidence. Herodotus was the first western scholar to mention horseback archery in literary evidence with the nomadic background. The detailed description of female archers in the Amazon tribe was the most shocking and alienated image for the Greek scholar at that age. The converse gender construction in the Scythian community from the literary evidence has always attracted lots of attention from western scholars. Historians had a strong willingness to find archaeological evidence about the female warrior in the Greek literary contexts. Unfortunately, early archaeologists have not paid much attention in determining the gender of diseases in the Scythian burial. Because the historical engendered stereotype from the western scholarship had always misled the typological method in the archaeological fieldwork, in some cases, the scholar will arbitrarily determine the gender of the deceased by the grave goods. Since several perfectly preserved archaeological remains were found in Pazyryk culture sites, especially the excavation in the site Ak-Alakha at 1993 summer, the progress of anthropological theory in gender studies has substantially promoted. An intact Scythian noble burial with a mummified female body has become the focus of many feminist archaeologists. The Pazyryk No.3 burials' distinctive grave goods reveal the high social status of deceased women in Scythian society. The socioeconomic status of mummified Scythian females has become a debatable subject to discuss the gender roles in the Scythian community. [3]

The site Ak-Alakha is an important archaeological site of Pazyryk culture, which is culturally belonged to the Scythian culture. The site is located near the Altai maintain and the stepped corridor, where is in the pathway of SilkRoad. The unique geographic location had impacted the Pazyryk culture with a substantial syncretized cultural characteristic. Hence, the nomadic Scythians who lived in this region played the role of trade route protectors, which were manipulated as patronized mercenaries of merchant groups in the trading networks. Since the SilkRoad was gradually established in the 3-4 $\mathrm{BCE}$, the increasing demands of Scythian mercenaries in the international labor market had provoked the female to participate in the onerous handworks more actively in the daily manipulation of the tribe. [3] Even some females had started to move beyond the traditional boundary of gender construction in the occupational specialization. There was no small number of females who had participated in the male's occupations, and some of the women had received high socioeconomic status in the tribe. Some Scythian females had engaged in the military occupation. According to Adrienne Mayor's 2014 book Bone: Archaeology of Amazon, there is 20 percent of 45 th c.BC graves contained the female warrior in the "Don-Volga" northern black sea region. The excavation of female burials had revealed a marvelous image to break the traditional stereotype for understanding the gender inequality in the nomadic groups. [4]

The Ak-Alakha No.3 burial was found within intact condition; the wooden burial chamber and the wooden sarcophagus were perfectly sealed without interruption. The burial pit was measured about $5 * 4$ meters, and the pits were shaped into a rectangular pattern. [5] The rectangular burial chamber was buried directly beneath the terrestrial tumuli; the frozen soil on the upper stratum had strengthened the preservation condition of the wooden burial chamber. The entire grave had generally followed the Scythian noble burial custom. The No.3 burial had fortunately avoided the plundering activities from Kara-Kobin populations; many of Pazyryk burials in the Ak-Alakha site were utterly plundered and were consecrated by the Kara-Kobin population during the 3rd-2nd century BC. There is a pronounced vestige of animal sacrifice and food sacrifice in the No.3 burial context. [5] Archaeologist teams found six horses' skeletal remains next to the northern wall of the wooden burial chamber. Although the taphonomy process decomposed the flesh of horses, the harness with wooden 
appliques has been perfectly preserved by frozen soil. The large-scale horse sacrifice indicated the high social status of a deceased individual in this nomadic society.

In contrast to the luxurious animal sacrifice, the grave goods in the wooden chamber have not amplified the high social rank of this deceased corpse which lay in the wooden sarcophagus. The grave goods that were found outside of the sarcophagus were mainly artifacts without prestigious identity, and those grave goods had included pottery, wooden vessel, wooden dish, and crafts made on an animal bone. Those grave goods revealed the modest feature of nomadic material culture. The wooden dish and wooden vessel are used to contain dairy products. [5]

The wooden sarcophagus was made on an intact wooden $\log$, and the frozen soil sealed the coffin lid and casket completely. The frozen anaerobic condition had helped the preservation of corpus in the wooden sarcophagus, which had perfectly mummified the body of the deceased individual. The corpus of the deceased individual belongs to a tall, aristocratic female. The hair and headdress were perfectly preserved. The silk tunics with metal applique were stretchable and intact - the metal applique in the headdress showed the highly decorative pattern of nomadic art. The iced mummy was properly manifested with the rite of passage, and the skins of the female corpus had been intentionally embalmed. The female body was intentionally mummified, and the organs and the muscle were intentionally replaced with horsehair. [3] Archaeologists found the tattoo with a mysterious theme in her corpus, and archaeologists believed that the tattoo possibly referred to her social status in the Scythian community. That is the reason why Scythian tried to preserve the soft tissue of this woman, possibly related to her noble status. According to Polosmak, she believed the tattoo is a universal phenomenon in a nomadic society, which could be applied to the preceding experience in nomadic archaeology to postulate the identity of this iced woman. Archaeologists believed that the iced woman possibly was a healing priestess in the Scythian community. [5]

The osteological analysis of the female skeletal remains in the Ak-Alakha site revealed an opposite phenomenon for my previous suggestion about the female's independent status. In the female burial from Ak-Alakha, most of the women had shaved heads, which had been postulated as a mark for showing family kinship linage. The activity of shaving the head seems a general cultural mark after the marriage. The high mobility of the pastoralist livelihood had increased the instability of marriage. The shaven heads could be viewed as emblematic chastity of women in the family kinship, which was significantly associated with marital relationship insurance. [4-5] The Scythian females were possibly viewed as property of their husbands, and the shave heads of females was a cultural custom for strengthening the unstable male-dominance marital relationship in the nomadic group. In my opinion, the general norm of the Scythian community was still constructed in an apparatus of male dominance, but the women could depend on other mediums to achieve the high rank and respective position in the tribe.

The several Pazyryk culture burials of the Altai region buried with female warriors and female nobles revealed the unique pattern of gender-egalitarian burials in the Scythian group. Even some Scythians women had ascended into the higher socioeconomic position. The imported luxuries found in the burial of Scythian noblewomen had revealed their high economic status in the community. The Pazyryk No.3 burial was a typical Scythian priestess burial. The mummified body of the priestess had preserved the tattoo with the religious emblems, which help archaeology postulate the identity of the women buried in the No.3 burial. The griffin icons in the tattoo showed the strong classical influences from the Greek world. The nomadic theme and classical artistic theme were juxtaposed in the Scythian tattoo art, which revealed the cultural syncretism under the silk road cultural construction. The imported silk products had been found in the Pazyryk No.3 noble burial. The elegant silk cloths with Persian style motifs have a complicated provenance; the Chinese silk was used for making the sumptuous cloths by Persian craftsman. [5] Also, the precious imported spices were found in the food sacrifice in the No.3 burial. The coriander originated from India and was found in the pot of food sacrifice by applying the palaeobotanical methodology to analyze the food remains in the pot. These two facts indicated the women who engaged in the religious affair could possess solid economic power in the tribe. Noblewomen used exotic goods and religious symbolism to contract their social prestige identity in the male-dominance society, which distinguishes them from submissive, low-class females. The noble female has shown their economic privilege and social privilege from this luxury burial. And their luxury enjoyment has strongly relied on the transcontinental trade networks. The high ranks Scythians became the beneficiary of being the patron of protecting the trade networks. The high-rank Scythian females could also gain their economic interests from this activity.

\section{THE GENDER CONSTRUCTION OF THE SCYTHIAN PEOPLE}

The warrior class was an important social caste in the Scythian society, and there is enough evidence to prove the fact that some Scythian women belonged to the warrior class. Great numbers of female warrior burials were found in the Ak-Alakha, determined by the projectile weaponry and the bronze mirror, buried in the mortuary context. The Scythian warrior burials have shown the general pattern of egalitarianism; the warrior's corpses were buried in the egalitarian cemetery regardless of their gender. The Scythians warrior enjoyed 
the animal sacrifice during their mortuary ritual. The intact bones of the horse were often found nearby the inhumation burial, a female warrior and male warrior enjoyed the same rank of animal sacrifice. [4] They were both treated with respect for their afterlife journey. The Altai region's cold weather has provided perfect conditions to preserve the organic material that had helped many artifacts made by organic material to be preserved in good condition. In the female warrior burial from Ak-Alakha No.1 burial, the adolescent female corpus was found with her bow and dagger next to the middle age male luxury sarcophagus. The archaeologists found the female warriors were buried with their weaponry and were buried with their well-preserved clothing, and the female warrior was found to be worn a trouser. Polosmak believed this female was intentionally buried with strong male-dressed features with socioeconomic concerns. In this case, I think this woman was buried in honor of a deceased male warrior. She was $170 \mathrm{~cm}$ tall, and she was an anatomically robust female. [4-5] Her health condition could support her to engage in horseback riding, and the projectile weapon proved that she could be a sophisticated archer. The trouser is a convenient invention for helping nomads in horseback riding, which indicated the women had possibly adopted the lifestyle of horseback arching. Their militarized dressings had shown the dynamic of the degenderizing process in the Scythian norm, and the female Scythian could receive the respect and glorified recognition by the participation of military tribune.

There is also some anatomical evidence from Pyzyrak sites could prove that female had directly participated in the warfare, and they have become the victims of cruel warfare. The archaeologist collected the samples from the Altai Scythian burials. Archaeologists mainly focused on the vestiges of wounds and healings. The perimortem wounds and the antemortem wounds are the direct evidence associated with the violent activities, and they can find the evidence direct evidence of engaging female warfare. In the case from $\mathrm{T} 10 \mathrm{~B}$, one female individual had suffered a perimortem injury in her right ribs from the dagger, which means this woman might be caused to death by this dagger's pit. Osteological archaeologists believed that a Scythian double edge dagger penetrated this 25-30-year-old female's right chest. She was the victim of warfare, but there is no robust evidence to convince her that she was a warrior. [6] In the city Ordzhonikidze at the Don-Volga region [7], archaeologists excavated the woman's bones with an arrowhead at her left knee in the kurgan 13 burial. An iron spearhead and few bronze arrowheads were found in the burial, and few female objects that include a mirror and ornament were also found next to the corpus. Those infantry weapons and battle wounds might indicate this woman was really joining the battlefield; she was a real warrior. Those degenderized artifacts indicate the complex gender construction of female warriors in the
Scythian community. The ages of female warriors were much older than preceding scholars expected, most of the female warriors were 20-40 years old, and some of them were buried with their children. Therefore, the Scythian female warriors may not have consisted of virgin females, and the Greek author might exaggerate the appearance of the Scythian female warrior into an unrealistic imaginary. [7-8]

\section{CONCLUSION:}

The gender construction of Scythian females is a complicated subject to discuss. Still, the archaeological evidence and the ancient literary source had to have an organized image for ruminating the reciprocal interrelation between the female-gendered apparatus and the grandiose geopolitical norms of the stepped corridor. The archaeological evidence reveals the mysterious praxis of female power in an iron age society. The religion, the unique geographical strategic location, and the resilience of nomadic livelihood, three important features in silk road nomadic lives, indirectly influenced the female gender construction's enculturation. The strong militaristic feature of Scythian females' gender construction is a marvelous projection of fluid gender construction in the Scythian community. The Pyzyrak burial and Don-Volga cemeteries will fulfill more knowledge gaps about Amazon female warriors in the predictable future.

\section{REFERENCES}

[1] Sauer, Eberhard W. "Herodotus and the Amazons Meet the Cyclops: Philology, Osteoarchaeology and the Eurasian Iron Age." Archaeology and Ancient History. Routledge, 2004. 181-96. Web.

[2] Ivantchik, Askold. "A Commentary on Herodotus. Books I-IV." Ancient Civilizations from Scythia to Siberia, vol. 14, no. 1-2, 2008, pp. 193-207. [1]. Sofidoc Productions (Producer), \& Levie, F. (Director). (1994). The Mystery of the Frozen Tombs of Siberia: A Young Lady Emerges from the Ice. [Video/DVD] Royal Anthropological Institute. Retrieved

from https://video.alexanderstreet.com/watch/themystery-of-the-frozen-tombs-of-siberia-a-younglady-emerges-from-the-ice

[3] Linduffand. K. M, Rubinson K. S, "Gender Archaeology in East Asia and Eurasia.” (2013) Wiley-Blackwell Companions to Anthropology: A Companion to Gender Prehistory, 2013, pp. WileyBlackwell Companions to Anthropology: A Companion to Gender Prehistory, 2013.

[4] Mayor, Adrienne. The Amazons: Lives and Legends of Warrior Women across the Ancient World. Princeton University Pres, 2016. 
[5] Polosmak, N.v. "The Burial of a Noble Pazyryk Woman." Ancient Civilizations from Scythia to Siberia, vol. 5, no. 3, 1999, pp. 125-163., doi:10.1163/157005799x00160.

[6] Jordana, Xavier, Galtés, Ignasi, Turbat, Tsagaan, Batsukh, D, García, Carlos, Isidro, Albert, . . . Malgosa, Assumpció. (2009). The warriors of the steppes: Osteological evidence of warfare and violence from Pazyryk tumuli in the Mongolian Altai. Journal of Archaeological Science, 36(7), 1319-1327.3.

[7] Guliaev, Valeri I. "Amazons in the Scythia: New Finds at the Middle Don, Southern Russia." World Archaeology, vol. 35, no. 1, 2003, pp. 112-125. JSTOR, www.jstor.org/stable/3560215. Accessed 30 Jan. 2021.

[8] Budin, Stephanie Lynn ; Turfa, Jean Macintosh. "Warrior Women: The Archaeology of Amazons." Women in Antiquity. Routledge, 2016. 1005-021. Web. 